\section{Insights into setting sites}

\section{Peter Aldhous}

The Fall-Safe Society: Community Deflance and the End of American Technological Optimism. By Charles Piller. Basic Books: 1991. Pp. 240. \$20.

NOT in my backyard! A new breed of environmental campaigner, the NIMBY activist, threatens the world's foremost technological society with paralysis. Across the United States, plans to build new waste dumps, factories and even basic research laboratories are being blocked by local residents. Agricultural biotechnology moves at a snail's pace, restrained by opposition to field tests of genetically engineered products; no new hazardous-waste dumps have been sited in a decade. To US technocrats, the picture painted by Piller must be depressingly familiar. In his book, billed as "the first balanced assessment" of the NIMBY phenomenon, Piller attempts to define the NIMBY activist, and to present US technological managers with a solution to a seemingly intractable problem. He can claim a degree of success in both of these tasks.

The book's core is a journalistic exposition of three case studies in NIMBYism: the opposition to the Department of Energy's Rocky Flats nuclear weapons production plant near Denver, Colorado; the controversy surrounding the first field trials of a genetically engineered bacterium; and the battle of the University of California at San Francisco (UCSF) with the residents of the affluent Laurel Heights suburb over plans to expand the university's biomedical research facilities. Piller provides lively accounts, interspersing the chronology of events with revealing profiles of the key players.

\section{Definitions}

Piller quickly makes the distinction between true NIMBY groups, usually ad hoc coalitions that dissolve once the battle against a perceived threat is over, and their occasional allies, the conventional environmentalists. He observes well the uneasy relationship between the local opponents to Rocky Flats, who care little about nuclear weapons so long as their gardens are free from plutonium, and the outside environmentalists and peace campaigners who share their protest against the plant.

Piller aims to show that the NIMBY response is remarkably consistent, and to dispel the technological establishment's criticism that NIMBY activists are modern luddites, ignorant of the technology they oppose and motivated entirely by selfishness. For this purpose, the case studies are well chosen. (But Piller's guide to the NIMBY movement would be more satisfying had he given more coverage to the 1978 Love Canal incident, which he identifies as the birth of NIMBYism as a political force. There, militant local opposition to chemical pollution led to the declaration by the Carter administration of the town in New York State as a federal disaster area.)

The Rocky Flats plant, at which many locals were employed, was viewed favourably by most of its neighbours for nearly four decades. But the scrutiny that followed a 1987 plan to open a new waste incinerator at the site revealed contamination of both the site and its groundwater with plutonium, and flagrant breaches of environmental regulations. Rocky Flats was closed by the Department of Energy in November 1989 and has yet to reopen.

In comparison, the dangers posed by UCSF's proposed expansion of its biomedical research facilities were trivial. But residents of Laurel Heights were nonetheless able to use environmental legislation to halt the university's plans to install laboratories in a vacated insurance-company building.

Completing the picture is 'ice-minus', a recombinant Pseudomonas bacterium lacking the genes for proteins that act as nuclei for the formation of ice crystals and therefore able to protect crop plants from frost damage. Although thought to be environmentally benign by biologists (similar Pseudomonas deletion mutants exist in nature), ice-minus, being a recombinant strain, nevertheless alarmed farmers in the Californian counties chosen for field tests. Geneticists found their plans blocked for more than three years; field tests eventually went ahead, with no apparent environmental problems.

As Piller shows, ignorance is not the cornerstone of NIMBYism. When NIMBY organizers delve into the technological details, their protests become more intense. Self-reliance, distrust of the technological establishment, and a desire to control decision-making emerge as NIMBYism's distinguishing marks. But that is as far as the parallels between the three outbreaks of NIMBYism go. The disruptive tactics and occasional factual distortions employed by the Rocky Flats opponents are defensible, their actions seemingly motivated by a legitimate instinct for self-preservation rather than by selfishness. But George Carr, and the other members of the Laurel Heights Improvement Association, deserve less sympathy.

Piller is so keen to prove the consistency of the NIMBY response, that he neglects an obvious interpretation of the actions of Laurel Heights' residents. Although the legal challenges to UCSF's plans were based on the possible danger of chemical and biological emissions, Carr originally complained about the disruption that an influx of delivery vehicles would cause in a cosy upper-middleclass neighbourhood, and about the possibility that meetings of the University of California Board of Regents would attract student protesters. One suspects that the environmental safety objections were always a secondary concern, but allowed Carr to play on public fears, and gave him the legal leverage needed to upset UCSF

\section{Solutions}

Piller's second task, finding a solution to the problem, is more formidable. NIMBY attitudes stem from a feeling of powerlessness, according to Piller. If the energy of NIMBY groups is to be harnessed for society's use, he argues, local people must become involved in technological decision-making. Environmental safety standards need to err more on the side of caution; full disclosure about development plans and their potential hazards is essential, and must reach the grass roots, not just a handful of existing local officials; trained community representatives should be responsible for enforcing agreed environmental performance standards, once a project is agreed. All this needs money, says Piller, including government grants to enable community organizations to muster the scientific expertise for their contribution to the debate.

Piller's recipe has much to commend it, but there are obstacles (and not just those of cost): the end of the Cold War notwithstanding, secrecy will remain a preoccupation of those responsible for the US nuclear-weapons complex. Piller dismisses the potential of financial compensation to placate communities asked to host toxic-waste dumps and the like. But one intriguing idea is not discussed. This involves an auction where the figure offered in compensation rises until one of the communities short-listed for the siting of a potentially hazardous facility accepts the offer (see Nature 347, 611; 1990). Superficially at least, this 'reverse Dutch auction' meets Piller's requirement of giving local people greater control over their own destiny.

Piller may not have all the answers, but his book is a thought-provoking starting point for an important and necessary debate. As he notes, the days of 'decide-announce-defend' as the standard mechanisms for siting locally unwanted facilities are over.

Peter Aldhous is a Nature staff reporter. 